\title{
Mitigation of Global Warming by using Renewable Energy Resource (Solar PV) in Awka, South East, Nigeria
}

\author{
Ike, C. U. (Ph.D) \\ Department of Physics/Ind. Physics Nnamdi Azikiwe University, Awka.
}

\begin{abstract}
Global warming is the recent challenge to the world. Governments of various countries in the world, at this time, are concentrating on the methods of reducing it. Both developed and developing countries like Nigeria are using fossil fuels in large quantity to meet their energy demands. The burning of fossil fuel produces $\mathrm{CO}_{2}$. The emission of $\mathrm{CO}_{2}$ in atmosphere is highly responsible for global warming. In this paper we discussed how we can combat global warming in Africa using renewabla energy resources (especially solar PV cells). This paper focuses on the installation of a $1 \mathrm{KW}$ monocrystalline panels which generate between 136 and $150 \mathrm{~V}$ on a good sunny day. We do store the generated power in our deep cycle Trojan batteries connected in series. We used a MPPT charge controller of 80 Amps to regulate the charging of the batteries. With the circuit breakers connected in the circuit and switches to the load (6 LED security lights) we do monitor for the effective use of the security lights at night. The PV cells were installed facing due South at an inclination of $6.3^{\circ}$ which is equal to the latitude of Awka in Anambra State, Nigeria.
\end{abstract}

Keywords: - Global warming, Renewable energy resources, $1 K W$ monocrystalline PV cells, MPPT charge controller, solar LED lamps.

\section{INTRODUCTION}

Global warming is the recent problem of the whole world. Governments and varous organisations of all developed and developing countries are trying to reduce it. Global warming is the usually rapid increase in Earth's average surface temperature over the past century primarily due to the greenhouse gases released by people burning fossil fuels [2]. There has been a rise in the global average surface temperature between 0.6 to 10 degrees Celsius for last hundred years [1] [2]. This is usually caused by green house effect. This is because near about $30 \%$ of incoming radiations from the sun are reflected back to space from the outer side of earth's atmosphere and remaining $70 \%$ enters the earth's atmosphere. From these radiations a fraction is absorbed by earth, and earth re-radiate this absorbed energy in form of heat called the infrared radiation. Green house gases such as carbon dioxide, nitrogen oxide, methane, fluorinated gases and water vapour absorb the heat caused by these infrared radiations and slow its escape from the atmosphere [5]. Thus infrared radiations remain in the earth's atmosphere for long time hence leading to the increase of the earth's surface temperature [6] [3]. Carbon dioxide emission is highly responsible for global warming [6], [4]. Various studies have shown that earth's average surface temperature could rise between $2^{\circ} \mathrm{C}$ and $5^{\circ} \mathrm{C}$ by the end of the $21^{\text {st }}$ Century [1] [2].

In this era, human life is highly dependent upon electrical energy, even we cannot think about life without electricity. But today most of electrical demand is met by conventional energy sources from fossil fuels. One of the reasons for the global warming is increasing population and hence increasing industrialization. It is expected by many scientists that if global warming will continue in the same way then it may deteriorate the life on earth and will lead to bad weather conditions [2] [1]. Whole world is engaged in searching the solution for global warming. In this paper, we introduced a very useful concept for mitigation of global warming: use of renewable energy resource, solar PV, which will not only reduce the global warming but will also give us electrical energy in Nnamdi Azikiwe University, Awka. In this paper we discussed the methodology of the installation of a $1 \mathrm{KW}$ solar powered security LED lights in the two female hostels of the university in Awka, Nigeria.

\section{EDFFQT CURVE}

Electrical Demand and Fossil Fuel Quantity v/s Time (EDFFQT) curve shows: there is need of renewable energy resources. As per the data of world for consumption of fossil fuel and electrical demand, a curve is drawn as shown in fig. 1 


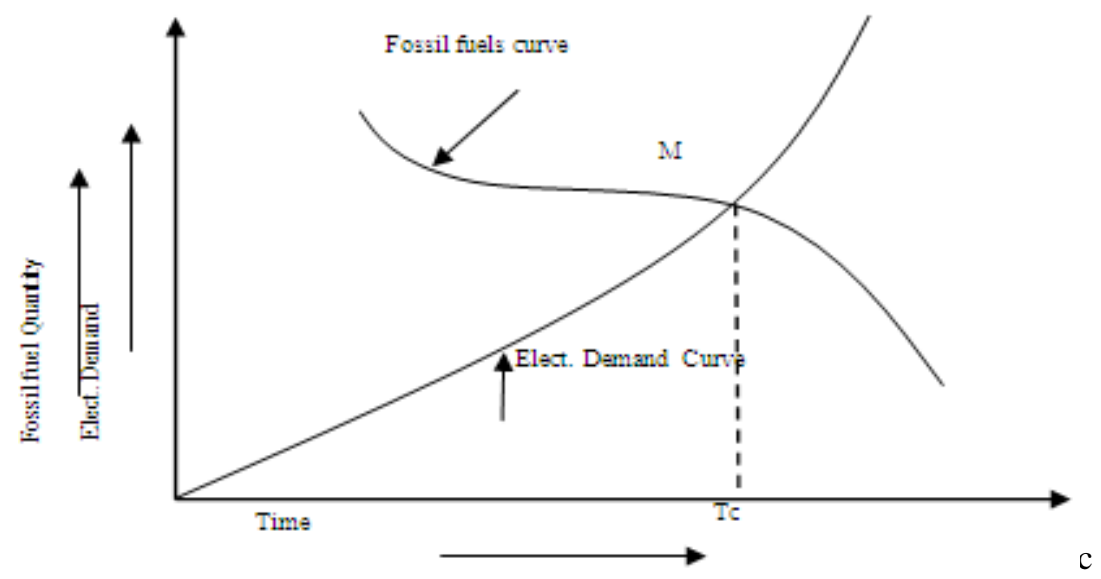

Fig. 1, EDFFQT curve

The curve shown in fig. 1 is an approximate curve which is only drawn to show that for meeting the future electrical demand, we should now go for renewable energy sources. In fig. 1, it can be seen that electrical demand curve is increasing, while the fossil fuel quantity curve is decreasing. There is a point of crossing of two curves, M. Up to point M; electrical demand curve is below fossil fuel curve; and hence electrical demand can be met by fossil fuels alone. After point $\mathrm{M}$, fossil fuel curve is below and hence electrical demand cannot be met by fossil fuels alone. The time corresponding to point M, is Tc. This time, Tc, is expected in next 200 years [2], the problem here is how to meet electrical demand after point, Tc. To meet this demand we should go for renewable energy sources, which will meet our electrical demand as well as save us from global warming and pollution.

\section{SOLAR PV FOR MITIGATION OF GLOBAL WARMING}

As we have seen that solar PV cells work on the direct conversion of sunlight (of proper wavelength) into electrical energy, so energy conversion is instantaneous. Solar PV cells do not covert heat energy into electrical energy but convert light (consisting of associated heat) of proper wavelength into electrical energy. In this way, solar PV cells will control the rate at which earth's mean temperature is increasing. Solar PV cells can make this rate of increasing of earth's temperature very small if they are used in large scale. A solar PV has no relation with the present or past temperate of the earth and also has no relation with the green house gases present in the atmosphere. Thus by using solar PV cells; we can decrease the rate of increase of earth's temperature. Hence, we say in general that by installing solar PVs with enough capacities at proper positions in the world we can mitigate the global warming.

\section{INSTALLATION OF SOLAR PV AT AWKA}

Recently, in January, 2013, we installed a solar PV in the two female hostels of Nnamdi Azikiwe University, Awka, Anambra State, Nigeria to power six security LED lights. Our installation consists of 1KW array of framed panels located on rack mounted on the ground at a site chosen in the open arena in between the 2 hostels as shown in fig. 2

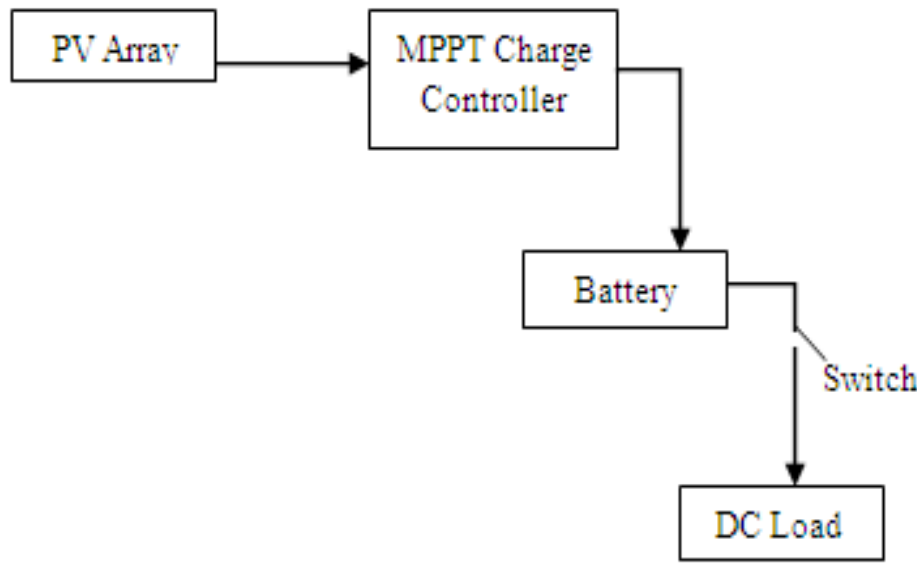

Fig. 2: The Solar PV system 
For maximum energy output, we installed the PV array due South at an inclination of $6.3^{\circ}$ which is equal to the latitude of Awka. We connected our MPPT Charge Controller 80 Amps to the battery bank. The batteries are the Trojan Deep Cycle batteries with a total of 30 Volts. Each of the LED lamp heads are watted 10 $-30 \mathrm{~W}$. There is the circuit breaker and switches connected to the load. In our installation we used solar PV cells in which the energy of light photons is converted into electrical energy. Using the relation;

$$
\mathrm{E}=\mathrm{E}_{\text {heat }}+\mathrm{E}_{\text {light }}+\mathrm{E}_{\text {other }}-----
$$

As we know solar radiations are in the range from UV to infrared $(0.1 \mu \mathrm{m}$ to $4.0 \mu \mathrm{m})$. Around $99 \%$ of solar radiations reaching the earth's surface are generally in region $0.3 \mu \mathrm{m}$ to $3.0 \mu \mathrm{m}$. Now radiations of proper wavelength (generally, $0.20 \mu \mathrm{m}$ to $1.15 \mu \mathrm{m}$ ) is converted into electrical energy by solar PV cells, and remaining radiations are not converted into electrical energy. Photons of light (of each wavelength) have associated heat energy, so equation (1) can be written as:

$$
\mathrm{E}=\mathrm{E}_{\text {light }}+\mathrm{E}_{\text {other }}-----
$$

Where $\mathrm{E}_{\text {light }}$ is combined energy of light and associated heat for whole range of wavelength of sun radiations reaching the surface of earth. Now by using the PV cells the energy (light and associated heat) of photons of proper wavelength will be converted into electrical energy. In this way the heat energy of those photons, which are converted into electrical energy. In this way the heat energy of those photons, which are converted into electrical energy, is prevented from being absorbed by earth and its re-radiation in form of infrared radiations.

But in the case if we are not using PV cells, the heat energy of photons (which was converted into electrical energy) will be absorbed by earth and will be re-radiated in form of infrared radiations, which will contribute to global warming because of green house gases.

We observed from the above that solar PV cell is an example of directly affecting renewable energy resource on global warming since it converts light (of proper wavelength and associated heat with the light photons) energy into electrical energy.

\section{CONCLUSION}

We introduced the EDFFQF curve to concentrate on the importance of renewable energy sources. An installation of a 1kWA array framed panel at the two female hostels of Nnamdi Azikiwe University, Awka, South East Nigeria show how we can mitigate global warming by using renewable energy resource. It is inferred that if we allocate solar PV cells at proper locations in the world, with enough capacities, we can overcome the problem of global warming. A new idea of directly affecting renewable energy resources on global warming was discussed. It was shown that solar PV cells are directly affecting renewable energy resource on global warming.

\section{REFERENCES}

[1] Bose B. K. (2009), "Global warming environmental pollution, and the impact of power electronics", IEEE Industrial Electronics, Magazine, Vol. 4, No. 1, pp 6 - 17

[2] Global warming and its bad effects, http://eathobservatory.nasa.gov/features/globalwarming.

[3] Green house effect, http://environment.about.com/od/globalwarming/a/grouhouse htm for about.com

[4] Jangra, M. K.; Parmar, K. P. S., Yadav, N. K., (2012), International Journal of Computer Science and Telecommunication, Vol. 3, No. 2

[5] Pal, S. (2009), "Wind energy An innovative solution to global warming" in $1^{\text {st }}$ International Conference on the development in renewable energy technology (ICDRET) pp $1-3$

[6] Sandrul Ula, A. H. M. (1999) "Global warming and electric power generative, what is the connection?" IEEE Transactions on Energy conversion, Vol. 6, No. 4

[7] Wansah, J. F., Oparaku, O. U., and Okeke, C. E., (2005), Pipeline corrosion control using PV modules: The Environmental Implications, Nigerian Journal of Physics, 17, pp 251 - 256. 